\title{
Memahami Makna Jihad Dalam Serial Film Kartun Cisform: Jihad Fi Sabilillah (Analisis Wacana Teun A. Van Dijk)
}

\author{
Ali Ridho \\ Universitas Islam Negeri (UIN) Sunan Kalijaga Yogyakarta \\ E-mail: ridhoali975@gmail.com
}

\begin{abstract}
This discourse analysis developed by Teun A. Van Dijk was used to find out the meaning of Jihad fi Sabilillah in the cartoon film series launched by the Center for the Study of Islam and Social Transformation (CISForm) UIN SunanKalijaga Yogyakarta, in collaboration with the Center for Middle East Studies and Peace Global (PSTPG) UIN StarifHidayatullah Jakarta. There are three text structures available in the Van Dijk discourse analysis including macro structure, superstructure and micro structure. This research is a descriptive type using a qualitative approach. With the data that the researcher obtained from the cartoon film CISForm: Jihad fi Sabilillah which was uploaded on youtube, various other supporting references such as books, journals and articles in mass media or the internet. The results of this study are that Jihad fi Sabilillah is able to be carried out in various ways, not just demonstration and war. Because, jihad in the form of demonstration for the establishment of khilafah and war in the context of the world order is now impossible to implement. And it violates the meaning and application of verses about jihad in the Qur'an and the Sunnah of the Prophet. Jihad in the present must have a direction to advance Islam for the benefit of mankind and the universe. The position of Jihad by studying religion or other sciences is more important than the position of jihad in taking up arms.
\end{abstract}

Keywords: CISForm, Islam, and Jihad

\begin{abstract}
Abstrak
Analisis wacana yang dikembangkan oleh Teun A. Van Dijk ini digunakan untuk mengetahui makna Jihad fi Sabilillah dalam serial film kartun yang diluncurkan oleh Center For The Study Of Islam And Social Transformation (CISForm) UIN Sunan Kalijaga Yogyakarta, bekerjasama dengan Pusat Studi Timur Tengah dan Perdamian Global (PSTPG) UIN Starif Hidayatullah Jakarta. Ada tiga struktur teks yang ada dalam analisis wacana Van Dijk diantaranya adalah struktur makro,
\end{abstract}


superstruktur dan struktur mikro. Penelitian ini merupakan penelitian dengan jenis deskriptif menggunakan pendekatan kualitatif. Dengan data-data yang peneliti peroleh dari film kartun CISForm: Jihad fi Sabilillah yang di-upload pada youtube, berbagai referensi pendukung lainnya seperti, buku-buku, jurnal dan artikel di media massa atau internet. Hasil penelitian ini adalah Jihad fi Sabilillah mampu dilakukan dengan beragam cara, tidak dengan demostrasi dan perang saja. Sebab, jihad bentuk demostrasi untuk penegakan khilafah dan perang dalam konteks tatanan dunia sekarang sudah tidak mungkin untuk dilaksanakan. Dan menyalahi pemaknaan dan penerapan ayat-ayat tentang jihad di al-Qur'an maupun Sunnah Nabi Saw. Jihad di masa kini harus mempunyai arah untuk memajukan Islam demi kemaslahatan manusia dan alam semesta. Kedudukan Jihad dengan mempelajari ilmu agama atau ilmu pengetahuan yang lainnya, lebih utama kedudukannya ketimbang dengan jihad mengangkat senjata.

Kata Kunci: CISForm, Islam, dan Jihad

\section{Pendahuluan}

Jihad merupakan kewajiban seorang mukmin untuk mempertahankan agamanya dari serangan lawan. Wujud dari serangan tersebut tidak harus berupa serangan fisik, akan tetapi dapat berupa serangan pemikiran, keilmuan, teknologi, perekonomian, dan lain sebagainya. Pada prakteknya, umat Islam dapat melakukan jihad dengan bersungguh-sungguh meningkatkan kualitas dari menjadi seorang pemikir, ahli di bidang keilmuan, teknologi, perekonomian, dan bidang-bidang lain yang rawan terjadi konflik antara orang Islam dan pihak lain yang berusaha untuk menghancurkan Islam. ${ }^{1}$

Disisi lain, belakangan ini tidak ada istilah paling sering disebut orang kecuali kata "terorisme" dan "jihad". Istilah ini justru dibelokkan sebagai tindakan "terorisme". Hampir dipastikan, istilah "jihad" merupakan salah satu konsep Islam yang sering disalahpahami, baik oleh kaum Muslimin maupun pengamat Barat, yang umumnya mengartikan jihad dengan perang. Aksi kekerasan yang berpijak pada konsep jihad merupakan bentuk penyempitan makna jihad. Dalam aksi kekerasan seperti pemboman, selain telah mendistorsi makna jihad juga menimbulkan tindakan-tindakan yang tidak sesuai dengan syariat seperti terbunuhnya wanita dan ank-anak. Kalangan "muslim radikal" lebih banyak memaknai jihad dengan perang dan segala bentuk kekerasan. Padahal, jihad memiliki makna yang luas, mencakup seluruh aktivitas yang membawa kemaslahatan bagi umat manusia secara keseluruhan.

Kemudian, kemajuan ilmu pengetahuan, tehnologi dan informasi beberapa dasawarsa sekarang ini memudahkan manusia untuk mengetahui perkembangan yang terjadi di belahan dunia lain, dalam hitungan detik dan menit. Seakan dunia menjadi miniatur mini yang mampu diketahui keadaannya setiap saat denga cepat. Diantaranya

1 Abdul Fatah, Memaknai Makna Jihad Dalam al-Qur'an dan Tinjauan Historis Penggunaan Istilah Jihad Dalam Islam, Jurnal Pendidikan Agama Islam, Vol. 3, No. 1 Juli-Desember (Malang: UIN Maulana Malik Ibrahim, 2016), 66 
adalah film-film kartun bergenre dakwah dan edukasi yang diberi nama CISForm UIN Sunan Kalijaga Yogyakarta. Dengan menampilkan Islam kelembutan, toleransi, hingga fenomena jihad fi sabilillah yang mampu dinikmati oleh masyarakat luas melalui internet.

Berangkat dari berbagai fakta diatas, peneliti berusaha membongkar bagaimana memahami makna Jihad dalam serial kartun CISForm UIN Sunan Kalijaga edisi: Jihad fi Sabilillah dengan menggunakan analisa wacana model Teun A. Van Dijk.

\section{Metode Penelitian}

Penelitian ini menggunakan jenis penelitian deskriptif dengan pendekatan kualitatif. Maksudnya adalah data-data yang dikumpulkan beruapa kata-kata, dokumen, gambar, dan bukan merupakan angka-angka. ${ }^{2}$ Deskriptif yaitu metode penelitian yang dapat diartikan sebagai prosedur pemecahan masalah yang diselidiki dengan menggambarkan atau melukiskan keadaan subyek atau objek penelitian (seseorang, lembaga, masyarakat dan lainnya), proses yang sedang berlangsung, dengan berdasarkan fakta-fakta yang tampak atau sebagaimana adanya. Sedangkan kualitatif adalah prosedur penelitian yang menghasilkan data deskriptif berupa kata-kata yang tertulis atau lisan dari objek yang diamati. ${ }^{3}$ Data dalam penelitian ini diperoleh dari film kartun cisform: Jihad fi Sabilillah yang di-upload pada youtube, berbagai referensi pendukung lainnya seperti, buku-buku, jurnal dan artikel di media massa atau internet. Dalam penelitian ini peneliti menggunakan metode analisis wacana model Teun A.Van Dijk untuk memahami makna Jihad dalam serial film kartun cisform: Jihad fi Sabilillah.

\section{Beberapa Pendapat Tentang Pengertian Jihad}

Kata Jihad berasal dari akar kata jahada, yajhudu, jahd au jubd arinya adalah sungguh-sungguh atau berusaha keras. ${ }^{4}$ Kata jahd atau jubd artinya tenaga, usaha atau kekuatan. Dari akar kata jahada (bentuk tsulatsi mujarrad) dibentuk tsulatsi mazid dengan menambahkan alif sesudah fa' fi'il atau suku pertama, sehingga menjadi jahada, yujabidu, mijahadah wa jihad. Berikut ini definisi menurut beberapa ulama atau cendikiawan pada masanya, yang masih relevan apabila ditarik benang lurus dengan zaman modern sekarang ini:

Pertama, menurut Syaikh Abdul Aziz bin Baaz menyatakan bahwa, jihad terbagi menjadi dua yaitu jihad at-tholab (menyerang) dan jihad ad-daf'u (bertahan). Maksud tujuan keduanya adalah meyampaikan agama Allah dan mengajak orang mengikutinya, mengeluarkan manusia dari kegelapan kepada cahaya Islam dan meninggikan agama Allah di muka bumi serta menjadikan agama ini hanya untuk Allah semata. ${ }^{5}$ Kedua, menurut Imam al-Bajuri mengatakan bahwa, jihad atau qital itu berarti perang di jalan Allah yang berasal dari kata al-mujahadah, yaitu perang untuk menegakkan agama dan (pengertian) ini yang dinamakan dengan jihad asghar, sedangkan jihad akbar adalah melawan hawa nafsu, mengingat sabda Nabi Saw. ketika

\footnotetext{
${ }^{2}$ Lexy J. Meleong, Metode Penelitian Kualitatif (Bandung: Remaja Rosdakarya, 2003), 11

${ }^{3}$ Sugiyono, Metode Penelitian Kuantitatif, Kualitatif, dan R\&D (Bandung: Alfabeta, 2014), 4

${ }^{4}$ Hasan Saleh, Kajian Fiqih dan Fiqih Kontemporer (Jakarta: IT Raja Persada, 2004), 274

5 Imam Malik Ibnu Anas, Al-Muwatta (Jakarta: Raja Fragindo Persada, 1999), 230
} 
beliau baru pulang, ketika beliau baru kembali daru medan perang “ kita baru kembali dari jihad ashgar menuju kepada jihad akbar. ${ }^{6}$ Ketiga, Sayyid Qutub mengartikan jihad di jalan Allah adalah sebagai perjuangan melawan musuh-musuh, perjuangan melawan diri sendiri dan perjuangan untuk melawan kerusakan dan kejahatan. Ketiganya adalah bentuk amanah besar yang diberikan oleh Allah Swt. ${ }^{7}$ Keempat, jihad menurut pandangan Imam 'llaa' al-Diin al-Kaasaaniy, di dalam kitabnya Badaai' al-Shanaai, mengatakan secara literal jïhad mempunyai makna mencurahkan segenap usaha dan tenaga atau ia adalah bentuk mubalaghah (hiperbolis) dari tenaga yang dicurahkan dalam suatu pekerjaan.

Sedangkan menurut 'uruf syara', kata jihad digunakan untuk menggambarkan pencurahan usaha dan tenaga dalam perang di jalan Allah Swt., baik dengan jiwa, harta, lisan (pendapat). ${ }^{8}$ Kelima, Imam Abu Hamid Muhammad bin Muhammad al-Ghazali (Hujjatul Islam) di dalam kitabnya Mukasyafatul Qulub mengatakan bahwa jihad itu terbagi menjadi tiga macam, 1) Jihad terhadap orang kafir. Jihad ini dinamakan dengan jhad dzahir yang di dalam al-Qur'an disebut "yujahiduna fisabilillab" (mereka yang berjihad di jalan Allah). 2) Jihad dengan dalil-dalil dan ilmu untuk menghadapi orang-orang dhalim. Ini disebutkan oleh al-Qur'an (adakanlah diskusi dengan mereka dengan jalan yang sebaik-baiknya). 3) Jihad melawan nafsu amarah (hawa nafsu). Ini disebutkan di dalam al-Qur'an "orang-orang yang berjïhad di jalan Kami, Kami Tunjukkan jalan-jalan Kami”. Sama halnya dengan hadits Nabi Saw. bahwa jihad yang paling baik adalah jihad melawan dirinya sendiri..." Keenam, Maududi mendefinisikan jihad sebagai mempertaruhkan hidup seseorang dan segala sesuatu yang dimilikinya untuk melenyapkan penguasaan manusia atas manusia dan menegakkan pemerintah yang tegak di atas syariat Islam. ${ }^{10}$

Jika disimpulkan pendapat para ulama dan cendikiawan diatas, di kalangan mereka secara garis besar terdapat dua garis pendapat dalam memaknai jihad. Pertama, berpendapat bahwa jihad identik dengan perang dan pembunuhan lawan, oleh karena itu Islam pada akhirnya diartikan oleh para sarjana Barat dengan pedang dan perang. Kedua, bahwa jihad tidak identik dengan perang dan pembunuhan, namun perang dinilai bentuk jihad kecil (asghar) dan perlawanan terhadap diri sendiri bernilai (jihad akbar).

Sementara itu Islam menggunakan istilah jihad kecil (jihad asghar) untuk mengacu pada apa yang di kalangan Kristen disebut perang yang adil (just war). Sedangkan istilah jihad besar (jihad akbar) mengacu pada perjuangan psikologis di dalam diri kita sendiri (jihad al-nafs) untuk membangun kerajaan Tuhan dalam perilaku kita dan membentuk gaya hidup yang mencerminkan ajaran Tuhan, baik dalam kehidupan

\footnotetext{
${ }^{6}$ Imam Malik Ibnu Anas, Al-Muwatta, 232

${ }^{7}$ Sayyid Qutb, Tafsir Fi Zilal al-Qur'an Jilid 8 (Jakarta: Gema Insani Press, 2003), 150-152.

8 Tengku Muhammad Habsi ash-Shidiegh, Ibya Ulumuddin, terj. (Semarang: Pustaka Riski,
} 2003), 510

${ }^{9}$ S. Ali Yasir, Jihad Masa Kini (Jakarta: Darul Kutubil Islamiyah, 2005), 14

${ }^{10}$ Deni Irawan, Kontroversi Makna dan Konsep Jihad Dalam al-Qur'an Tentang Menciptakan Perddamaian, Jurnal Religi, Vol X, No. (Yogyakarta: Universitas Islam Negeri (UIN) Sunan Kalijaga: 2014), 68 
individu maupun komunal atau kelompok. ${ }^{11}$ Sedangkan Robert Bellah di dalam bukunya The Good Society menjelaskan bahwa jihad sendiri sebenarnya mempunyai tujuan membangun apa yang disebut para filosof barat sebagai masyarakat yang baik (good society)..$^{12}$

\section{Dasar Hukum Berjihad}

Di dalam salah satu firman-Nya Allah Swt. menerangkan yang artinya: "Dan berjihadlah kamu pada jalan Allah dengan Jihad yang sebenar-benarnya. Dia telah memilih kamu dan Dia sekali-kali tidak menjadikan untuk kamu dalam agama suatu kesempitan. (Ikutilah) agama orang tuamu Ibrabim. Dia (Allah) telah menamai kamu sekalian orang-orang Muslim dari dabulu, dan (begitu pula) dalam (Al Quran) ini, supaya Rasul itu menjadi saksi atas dirimu dan supaya kamu semua menjadi saksi atas segenap manusia, Maka dirikanlah sembahyang, tunaikanlah zakat dan berpeganglah kamu pada tali Allah. Dia adalah Pelindungmu, Maka Dialah Sebaik-baik pelindung dan sebaik-baik penolong”. (Surah al-Hajj ayat 78)

Di ayat yang lainnya Allah Swt. juga menyinggung tentang perlunya para hamba-Nya untuk melaksanakan jihad. Seperti di dalam surah Al-'Ankabut ayat 69, yang artinya: "Dan orang-orangyang berjihad untuke (mencari keridhaan) Kami, benar-benar akan Kami tunjukekan kepada mereka jalan-jalan kami. dan Sesunggubnya Allab benar-benar beserta orangorang yang berbuat baik".

Kemudian, di dalam hadits yang diriwayatkan oleh Ad-Dailami ra. yang berbunyi yang artinya: "Kita pulang dari pertempuran yang kecil menuju pertempuran yang besar". (HR. Ad-Dailami) $)^{13}$

\section{Problematika Memaknai Jihad}

Dalam konteks kekinian, apabila kita mendengar kata jihad barangkali yang tergambar di dalam otak bawah sadar adalah orang-orang yang sedang mengangkat senjata dengan mengendarai kuda hingga kendaraan berat yang terbuat dari bahan besi dan dilapisi oleh baja yang tebal. Jihad digambarkan dengan membunuh orang-orang yang tidak ber-istinbath (baca: mengambil hukum) dari hukum Allah Swt. yaitu al-Qur'an dan As-Sunnah. Jihad digambarkan dengan menumpahkan darah secara kejam, hanya karena perbedaan-perbedaan dalam permasalahan khilafiyah sederhana, bukan

11 Zakiya Drajat, Jihad Dinamis: Menelusuri Konsep dan Praktik Jihad Dalam Sejarah Islam, Jurnal Wacana Hukum Islam dan Kemanusiaan, Vol. 16. No. 1 Jakarta: Universitas Negeri Jakarta, 2016), 4

12 Robert Bellah et al., The good Society, 1992

13 Ibnu Taimiyah, As-Siyasah asy-Syar'iyah fi Ishlabi ar-Ra'I wa al-Ra'iy-yah (Mesir: Dar alKitab al-'Arabi, 1951), 177; Hadits ini cukup populer di kalangan umat Islam. namun penulis belum menemukan sand dan matannya yang lebih lengkap, terutama di dalam kutub at-Tis'a Sehingga perlu dilakukan penelitian (takbrij) lebih lanjut. Sementara menurut Hasan al-Banna, bahwa hadis tersebut ketika melihat orang-orang Islam berada di bawah imperialism barat, mengkritik pemahaman yang memperkecil peran dan arti jihad melawan musuh yang nyata sebagai jihad kecil (al-jibad al-ashgar). Ia juga mengkritik pemahaman yang memperbesar peran dan arti jihad spiritual sebagai jihad besar (al-jibad al-akbar). Lihat Hasan al-Banna, Risalah al-jibad, (Kuwait: al-Ittihad AL-'Alami li al-Munazhamat ath-Thullabiyyah, 1985), 7-59 
menjerumus kepada perbedaan akidah atau keimananan diantara sesamanya. Jihad digambarkan dengan pengemboman atas nama membela agama dan melawan pemerintahan yang berkiblat kepada thagut (baca: sesembahan selain Allah Swt.) yang pada akhirnya menimbulkan korban dari jiwa-jiwa yang tak bersalah dan tiada mengetahui apa kesalahan mereka? Para istri menjadi janda, para suami menjadi duda, para anak menjadi yatim dan yatim-piatu. Masjid bukan lagi tempat yang suci dan aman untuk melaksanakan ritual ibadah, ketika dengan ringan terjadi penumpahan darah. Bangunan-bangunan penuh dengan nilai-nilai estetika dan sejarah kemajuan sebuah peradaban Islam kuno yang tak bersalah dengan beringasnya dihancurkan. Hingga makam-makam Nabi dan ulama serta waliyullah (baca: orang-orang yang menjadi kekasih Allah Swt.) diledakkan dan rata dengan tanah. Dan yang terbaru adalah zaman berkemajuan di tengah-tengah terjangan deras arus globalisasi barat yang memaksa untuk merubah tatanan dunia, jihad digambarkan dengan suatu sikap apriori yaitu suatu bentuk klaim akan kebenaran yang sejati, yang menjadikan pelakunya rabun untuk memandang khazanah nilai-nilai kebenaran yang juga dimiliki oleh orang lain.

Jihad dimaknai dengan sikap arogansi. Sikap yang seharusnya tidak ada pada pribadi seorang muslim, dan apabila seseorang mulai terjangkit sifat tersebut hendaknya segera untuk sadar untuk bersegera membersihkannya. Sikap arogansi pada akhirnya menghantarkan pemiliknya kepada kotoran batin yaitu Sok Suci dan itu adalah suatu bentuk kesombongan, dan al-Qur'an mengatakan Allah tidak suka kepada orang yang sombong. Hadits mengatakan bahwa pintu yang paling rapat menutup orang masuk surga adalah kesombongan. Itulah dosanya iblis. Ketika Allah meminta iblis bersujud kepada Adam, iblis menolak karena merasa lebih tinggi dari Adam, padahal para malaikat saja bersujud. Maka kata Allah, aba wastakbara wa kana min al-kafirin (ia enggan dan takabur, dan ia adalah termasuk golongan kafir. (QS. Al-Baqarah: 34) tidak usah sombong dan sok suci.

Arogansi dalam memahami agama muncul manakala seseorang atau kelompok mencerna suatu permaslahan apa yang tampak di permukaan, enggan menelisiknya dari sudut pandang yang lebih dalam. Bahwa sesungguhnya kesemuanya adalah proses menjalani takdir kehambaan. Hal tersebut apabila tidak mampu dipahami oleh hati kecil manusia, maka jiwanya akan gersang. Manusia sedang melesat keluar dari orbit spiritnya. Dia mencoba membangun kerajaan sendiri, atau planet-planet sendiri, di dalam kehidupan ini. Manusia kemudian terlepas dari fitrahnya. Lalu, menjadi kaku dalam memandang setiap persoalan yang berada pada tatanan masyarakat yang majemuk. Timbullah klaim bahwa perbuatan atau amal yang dilakukannya adalah benar, dan yang berbeda adalah salah. Disini manusia sudah mengambil hak preogatif Tuhan dengan stampel benar atau salah yang seharusnya menjadi wilayah ke-Tuhanan dijadikan untuk dirinya sendiri. Disini sudah kita temukan dua klaim yang dilakukan oleh manusia pertama, amal yang dilakukanya dijadikan legitimasi atau paspor untuk mem-booking surga. Kedua, manusia sendiri-lah yang menjadi pemilik daripada surga, bukan Allah Swt.

Posisi umat Islam yang arogansi dalam memahami agama ini oleh KH Luqman Hakim (Direktur Sufi Center), mirip orang "kebelet” mau ke kamar kecil. Saking tidak sabaran, ia menggedor-gedor pintu. Islam "kebelet" ini dengan modal pengetahuan dia yang sedikit tentang Islam, ingin agar segala sesuatunya selesai atas nama Islam. Nah, 
setelah masuk ke bilik air, ada yang namanya Islam "ngeden" (baca: mengejan). Ia paksakan segala sesuatunya atas nama Islam, tetapi sesungguhnya itu nafsu belaka.

Fakta-fakta diatas menjadi suatu duri yang seakan menancap di hati para orangorang yang mencoba peduli dengan keadaan yang menggelisahkan, menyedihkan dan menyayat nurani hamba-hamba beriman. Melihat bagaimana saudara-saudaranya seiman di belahan negeri yang asing merindukan kedamaian. Merindukan belaian kasih-sayang.

Membangun kesadaran kembali (baca: dakwah) akan pentingnya kelembutan dalam memahami agama merupakan bagian terpenting bagi kita yang sudah lelah dengan fenomena-fenomena yang terjadi di depan mata. Di zaman yang berkemajuan sekarang ini dakwah tidaklah cukup dengan disampaikan melalui lisan tanpa bantuan dari alat-alat modern yang dikenal sebagai alat komunikasi massa. Diantaranya adalah film, televisi, radio, handphone, media cetak dan lain sebagainya. Kata-kata yang diucapkan melalui lisan manusia hanya mampu menjangkau jarak yang terbatas, sedangkan apabila menggunkan alat komunikasi massa, dapat dijangkau jarak yang luas melampaui ruang dan waktu. ${ }^{14}$ Media massa modern pada umumnya di kendalikan secara lebih baik dan biasanya melibatkan organisasi atau lembaga dengan profit dan non profit. Media massa modern misalnya, musik, film, industry media massa, tehnologi telepon, telepon seluler, computer, internet dan lainnya. ${ }^{15}$

\section{Landasan Teori}

Teori model analisis wacana yang dipopulerkan oleh Teun A. Van Dijk. Dari sekian banyak model analisis wacana yang diperkenalkan dan dikembangkan oleh beberapa ahli, barangkali model van Dijk adalah model yang paling banyak dipakai. Model yang dipakai oleh van Dijk ini seing disebut sebagai "kognisi sosial". Menurut van Dijk, penelitian atas wacana tidak cukup hanya didasarkan pada analisis atas teks semata, karena teks hanya hasil dari suatu praktik produksi yang harus diamati. Disini juga harus dilihat juga bagaimana suatu teks diproduksi, sehingga kita memperoleh suatu pengetahuan kenapa teks bisa semacam itu. ${ }^{16}$

Van Dijk mencoba tidak mengeksklusi modelnya semata-mata dengan teks saja. Ia juga melihat bagaimana struktur sosial, dominasi, dan kelompok kekuasaan yang ada dalam masyarakat dan bagaimana kognisi/pikiran dan kesadaran yang membentuk dan berpengaruh terhadap teks tertentu. Wacana oleh van Dijk digambarkan mempunyai tiga dimensi/bangunan: Pertama, teks. Kedua, kognisi sosial. Ketiga, konteks sosial. Ciri dari analisis van Dijk adalah menggabungkan tiga dimensi wacana tersebut ke dalam satu kesatuan analisis. Model dari analisis van Dijk ini dapat digambarkan sebagai berikut ${ }^{17}$ :

${ }_{14}$ Abdul Munir Mulkhan, Arah Ideologi Gerakan Dakwah (Yogyakarta: SIPRESS, 1996), 58

15 Wahyu Ilahi, dkk, Komunikasi Dakwah (Surabaya: IAIN Sunan Ampel Press, 2013), 153-154

${ }^{16}$ Eriyanto, Analisis Wacana: Pengantar Analisis Teks Media (Yogyakarta: LKiS, 2015), 221

${ }^{17}$ Eriyanto, Analisis Wacana: Pengantar Analisis Teks Media, 224-225 
Bagan. 1.1

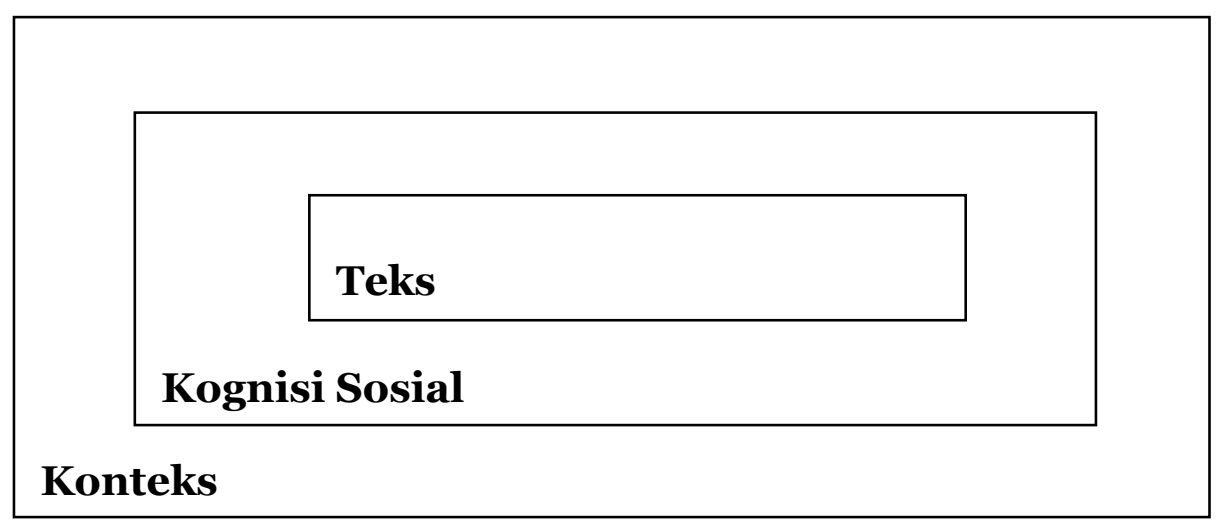

\section{Analisis Sosial}

Dalam dimensi teks, yang diteliti adalah struktur dari teks. Van Dijk memanfaatkan dan mengambil analisis linguistic tentang kosakata, kalimat, preposisi, dan paragraf untuk menjelaskan dan memaknai suatu teks. Kognisi sosial merupakan dimensi untuk menjelaskan bagaimana suatu teks diproduksi oleh individu atau kelompok pembuat teks. Cara memandang atau melihat suatu realitas sosial itu yang melahirkan teks tertentu. Munculnya berita yang buruk mengenai orang China, misalnya, timbul akibat struktur pikiran tertentu yang membentuk suatu cara melihat persoalan sehingga mempengaruhi bagaimana suatu teks diproduksi. Sedangkan analisis sosial melihat bagaimana teks itu dihubungkan lebih jauh dengan struktur sosial dan pengetahuan yang berkembang dalam masyarakat atas suatu wacana. Ketiga dimensi ini merupakan bagian yang integral dan dilakukan secara bersama-sama dalam analisis van Dijk. ${ }^{18}$

\section{Teks}

Van Dijk melihat suatu teks terdiri atas beberapa struktur atau tingkatan yang masing-masing bagian saling mendukung. Ia membaginya menjadi tiga tingkatan. Pertama, struktur makro, merupakan makna global atau umum dari suatu teks yang diamati dengan melihat topic atau tema yang dikedepankan dalam suatu berita. Kedua, superstruktur, merupakan struktur wacana yang berhubungan dengan kerangka suatu teks, bagaimana bagian-bagian teks tersusun ke dalam berita secara utuh. Ketiga, struktur mikro, merupakan makna wacana yang diamati dari bagian kecil dari suatu teks yakni, kata, kalimat, proposisi, anak kalimat, paraphrase, dan gambar. Kalau digambarkan maka struktur teks dalam analisis wacana van Dijk adalah sebagai berikut ${ }^{19}$ :

\section{Tabel 1.1}

${ }^{18}$ Eriyanto, Analisis Wacana: Pengantar Analisis Teks Media, 225

${ }^{19}$ Eriyanto, Analisis Wacana: Pengantar Analisis Teks Media, 226-227 


\section{Struktur Makro}

Makna global dari suatu teks yang dapat diamati dari topik atau tema yang diangkat oleh suatu teks.

\section{Superstruktur}

Kerangka suatu teks, seperti bagian pendahuluan, isi, penutup, dan kesimpulan.

\section{Struktur Mikro}

Makna lokal dari suatu teks yang dapat diamati dari pilihan kata, kalimat dan gaya yang diapaki oleh suatu teks.

\section{Kognisi Sosial}

Analisis wacana tidak hanya membatasi perhatiannya pada struktur teks, tetapi juga bagaimana suatu teks diproduksi. Van Dijk menawarkan suatu analisis yang disebut sebagai kognisi sosial. Dalam kerangka analisis wacana van Dijk, perlu ada penelitian mengenai kognisi sosial: kesadaran mental wartawan yang membentuk teks tersbut. Dalam pandangan van Dijk, analisis wacana tidak dibatasi hanya pada struktur teks, karena struktur wacana itu sendiri menunjukkan atau menandakan sejumlah makna, pendpat, dan ideology. Untuk membongkar bagaimana makna tersembunyi dari teks, kita membutuhkan suatu analisis kognisi dan konteks sosial. Pendekatan kognitif didasarkan pada asumsi bahwa teks tidak mempunyai makna, tetapi makna itu diberikan oleh pemakai bahasa, atau lebih tepatnya proses kesadaran mental dari pemakai bahasa. Oleh karena itu, dibutuhkan suatu penelitian atas representasi kognisi dan strategi wartawan dalam memproduksi suatu berita. Karena setiap teks pada dasarnya dihasilkan lewat kesadaran, pengetahuan, prasangka, atau pengetahuan tertentu atas suatu peristiwa. ${ }^{20}$

\section{Hasil Penelitian dan Pembahasan}

Film ini diluncurkannya oleh Center For The Study Of Islam And Social Transformation (CISForm) UIN Sunan Kalijaga Yogyakarta, bekerjasama dengan PSTPG UIN Starif Hidayatullah Jakarta adalah diantaranya sebagai upaya penanggulangan dan pencegahan aksi terorisme di berbagai daerah di hampir seluruh wilayah Indonesia, khususnya ditujukan untuk para generasi muda yang sangat rentan terpapar ideology ekstrimisme.

Sebagaimana yang beritakan oleh situs uinsuka.ac.id pada tanggal 29 Januari 2018 dijelaskan bahwa dalam rangka memfasilitasi berbagai pengalaman dan pengetahuan terkait penanganan dan pengetahuan terkait penanganan tindakan ekstrimisme, CISForm UIN Sunan Kalijaga Yogyakarta dan PSTPG UIN Syarif Hidayatullah Jakarta menyelenggarakan workshop dengan tema "Penguatan Jaringan Masyarakat dan Pemerintahan Dalam Penanggulangan Terorisme", di Hotel Grand

${ }^{20}$ Eriyanto, Analisis Wacana: Pengantar Analisis Teks Media, 259-260 
Zuri Yogyakarta, (29/01/2018). Di dalam forum tersebut memaparkan beberapa materi pokok seperti tantangan radikalisme, penguatan penanggulangan terorisme dan best practice penanganan terorisme dengan narasumber: Pertama, Dr. Najib Azcka dari PSKP Universitas Gadjah Mada (UGM). Kedua, Dr. Nostalgiawan Wahyudi dari Pusat Studi Timur Tengah dan Perdamaian Global (PSTPG) UIN Syarif Hidayatullah. Ketiga, Alimatul Qibtiyah, M.A., Ph.D dari CISForm UIN Sunan Kalijaga. Keempat, KH. Abdul Muhaimin dari FKPT Yogyakarta. Kelima, AKBP Sinungwati, SH., M.I.P dari Polda DIY. Keenam, Dr. Muhammad Wildan dari CISForm UIN Sunan Kalijaga. Ketujuh, Dr. M. Fajar Sodik dari Ngruki Solo. Kedelapan, Widodo Kainan dari Dapoer Bistik Solo. Dan yang terakhir adalah Eko Prasetyo dari SMI UII Yogyakarta.

Direktur CISForm UIN Sunan Kalijaga Dr. Muhammad Wildan menuturkan "saat ini kami sedang menyelesaikan serias video pendek untuk menanggulangi aksi terorisme. Kampanye ini rencananya ada 40 film animasi yang terbagi dalam lima tema religi yakni hijrah, khilafah, jihad, toleran dan tauhid. Semuanya akan kami upload ke youtube untuk masyarakat khususnya kaum muda. Tutur Wildan. Sementara Muhammad Najib Azca di sisi lain menerangkan, bahwa perhatian terhadap potensi terorisme belum begitu disadari oleh anak muda. Mereka rentan terhadap merebaknya ajaran-ajaran radikal. Kondisi ini yang harus menjadi perhatian serius semua pemangku kepentingan. Dalam kasus Islam Radikal terbagi menjadi tiga kategori, yakni Jihadisme, Vigilatisme dan Syariatisme. Ketiganya memiliki tingkatan yang berbeda dalam pemikiran dan tindkannya. Namun demikian, ketiganya perlu diwaspadai. Sebab sasarannya jelas pada anak muda. Pola rekrutmennya juga melalui media sosial. Bahkan, rentan pula terjadi pada pekerja migrant perempuan seperti kasus di Hongkong beberapa waktu lalu saat TKI terindikasi dengan Islamic State of Iraq and Suriah.

Sementara Dr. Nostalgiawan Wahyudi dari Pusat Studi Timur Tengah dan Perdamian Global (PSTPG) UIN Syarif Hidayatullah Jakarta mengatakan, program pemberdayaan ekonomi bagi generasi muda menjadi salah satu langkah penting untuk meminimalisir menyebarnya paham radikal. Ada tiga kelompok besar menurut Nostalgiawan, yang dinilai perlu mendapatkan perhatian dengan permberdayaan tersebut. Pertama, untuk bekas napi teroris (napiter) yang butuh pemberdayaan ekonomi dan proses deradikalisasi agar tidak kembali ke jalan yang salah. Kedua, untuk pemuda yang butuh pemberdayaan ekonomi sebagai bahan pencegahan. Dan yang ketiga, bagi pelajar atau mahasiswa butuh pemberdayaan pendidikan.

Kemudian, Alimatul Qibtiyah, M.A., Ph.D dari CISForm menerangkan bahwa Islam yang berkembang di Indonesia merupakan Islam tengahan di antara tarik ulur paham kanan dan kiri. Sehingga menunjukkan jati dirinya untuk meladeni pahampaham ekstrim dan radikal. Alimatul juga mengingatkan, jika para perempuan juga mulai rentan terkena imbas paham radikal, hal tersebut sudah terbukti dengan sejumlah fakta peran perempuan dalam kasus-kasus terorisme yang berhasil diungkap oleh kepolisian atau dalam hal ini adalah mewakili pemerintah. ${ }^{21}$ Secara resmi peluncuran fil animasi religi oleh CISForm dilakukan di dua tempat berbeda, 20 film pertama di luncurkan di UIN Sunan Kalijaga, Yogyakarta sedangkan 20 sisanya diluncurkan pada tanggal 18 April 2018 di UIN Syarif Hidayatullah, Jakarta. Film animasi religi CISForm

${ }^{21}$ http://uin-suka.ac.id diakses pada tanggal 01 Desember 2018 
ini masing-masing berdurasi antara $1,5 \mathrm{~s} / \mathrm{d} 2$ menit dan berjumlah 40 buah film. Film animasi religi ini merupakan komitemen CISForm untuk mengatasi penyebaran narasi Islamisme dan radikalisme (counter violent extremism) di Indonesia. Pada peluncuran di Jakarta, acara diisi dengan pemutaran film animasi religi dan dilanjutkan dengan diskusi bersama tokoh agama dan utusan dari negara Syria. Kegiatan tersebut dihadiri oleh berbagai perwakilan seperti pelajar SMA sederajat, guru-guru, remaja masjid, ustadz pesantren, mahasiswa, lembaga pemerintahan, ormas keagamaan, dan akademisi.

Ketua CISFform mengatakan, "bahwa CISForm konsen dalam menangani fenomena radikalisme melalui pendekatan yang lunak dan moderat". Sebuah studi terbaru menyatakan bahwa rata-rata kebiasaan membaca kaum muda di Indonesia kurang dari $10 \%$. Sedangkan disisi yang lain, media sosial online lebih dipilih menjadi alternatif yang cukup efektif untuk mendapatkan isu-isu terbaru. Hal ini didukung oleh sebuah kenyataan bahwa banya pemuda akhir-akhir ini yang lebih suka memilih akses mudah mencari melalui gadget dan internet dalam mencari dan mempelajari segala hal termasuk dalam belajar ilmu agama. CISForm menyadari bahwa tidak bisa dipungkiri bahwa arus globalisasi dan kemajuan tehnologi informasi, paham extremisme dan radikalisme menyebar dan berkembang dengan pesat. Media sosial merupakan media paling rawan untuk penyebaran ideology ultra-konservatif seperti Islamic State of Iraq and Syria (ISIS). Gerakan-gerakan ultra konservatif tersebut menyebarkan ideology (propaganda) mereka khususnya ke generasi muda dengan narasi-narasi extremisme dan radikalisme. Wildan juga mengatakan, "Berdasarkan pengamatan dan penelitian yang dilakukan oleh CISForm, ideologi yang dikembangkan oleh gerakan-gerakan extremism adalah seputar narasi hijrah, jihad, khilafah, dan intoleransi". Berangkat dari hal tersebutlah, CISForm pada akhirnya berusaha untuk menangkal perkembangan ideologi ultra konservatif tersebut dengan membuat film animasi religi yang berisi pesan-pesan Islam moderat. ${ }^{22}$

Dalam analisis model Teun A. van Dijk bukan hanya isi teks saja yang dipahami, tetapi juga bagaimana pesan yang disampaikan dalam serial film kartun CISForm: Jihad fi Sabilillah. Dengan berbagai struktur wacana meliputi struktur makro, superstruktur dan struktur mikro serta hal yang diamati seperti elemen tematik, skematik, semantik, sintaksis, stilistik dan retoris mampu disampaikan oleh sebuah serial film kartun CISForm: Jihad fi sabilillah.

Tabel 1.3

\begin{tabular}{|l|l|l|}
\hline \multicolumn{1}{|c|}{ Struktur wacana } & \multicolumn{1}{|c|}{ Hal yang diamati } & \multicolumn{2}{|c|}{ Elemen } \\
\hline $\begin{array}{l}\text { Struktur Makro } \\
\text { Serial film kartun } \\
\text { CISForm: Jihad fi sabilillah }\end{array}$ & $\begin{array}{l}\text { Tematik } \\
\text { Seruan untuk mengikuti aksi } \\
\text { demostrasi dan jihad di } \\
\text { sebuah Masjid }\end{array}$ & $\begin{array}{l}\text { Topik dan Udin dalam } \\
\text { percakapan tentang Jihad } \\
\text { fi sabilillah }\end{array}$ \\
\hline $\begin{array}{l}\text { Super Struktur } \\
\text { Mengikuti }\end{array}$ & $\begin{array}{l}\text { Skema aksi } \\
\text { Dengan dialog atau }\end{array}$ & $\begin{array}{l}\text { Tema } \\
\text { Permasalahan tentang }\end{array}$ \\
\hline
\end{tabular}

${ }^{22}$ http://Republika.co.id diakses pada tanggal 31 November 2018 
12 |Jurnal Dakwah dan Komunikasi, Vol. 4 , No.1, 2019

\begin{tabular}{|c|c|c|}
\hline demostrasi dan jihad & percakapan & $\begin{array}{l}\text { pemaknaan jïhad antara } \\
\text { Ari dan Udin dengan } \\
\text { disajikan melalui dialog } \\
\text { atau percakapan singkat }\end{array}$ \\
\hline Struktur Mikro & Skematik & Latar Detail \\
\hline $\begin{array}{lr}\text { Semangat } & \text { yang } \\
\text { menggebu-gebu } & \text { untuk } \\
\text { mengajak } & \text { dan } \\
\text { melaksanakan } & \text { jihad fi } \\
\text { sabilillah } & \end{array}$ & Pemaknaan jibad fi sabilillab & $\begin{array}{l}\text { Mencoba memberi } \\
\text { penertian yang lebih } \\
\text { mendalam tentang makna } \\
\text { jihad fi sabilillah }\end{array}$ \\
\hline Struktur Mikro & Sintaksis & Bentuk Kalimat \\
\hline $\begin{array}{l}\text { Seruan untuk } \\
\text { melaksanakan jihad }\end{array}$ & $\begin{array}{l}\text { Dialog atau percakapan } \\
\text { tentang seruan dan } \\
\text { pemaknaan tentang jihad } \\
\text { melalui bentuk cerita non- } \\
\text { fiksi }\end{array}$ & $\begin{array}{l}\text { Udin mengajak Ari untuk } \\
\text { melakukan jihad fi } \\
\text { sabilillah }\end{array}$ \\
\hline Struktur Mikro & Stilistik & Leksikon \\
\hline $\begin{array}{l}\text { Dialog ringan di dalam } \\
\text { Masjid }\end{array}$ & $\begin{array}{l}\text { Bahasa pergaulan anak } \\
\text { muda yang lagi mencari jati } \\
\text { diri }\end{array}$ & $\begin{array}{l}\text { Udin mengajak Ari untuk } \\
\text { melaksanakan jihad fi } \\
\text { sabilillah }\end{array}$ \\
\hline $\begin{array}{l}\text { Struktur Mikro } \\
\text { Ari bergegas } \\
\text { meninggalkan Udin }\end{array}$ & $\begin{array}{l}\text { Retoris } \\
\text { Pengucapan kalimat } \\
\text { penutup percakapan yang } \\
\text { dilakukan oleh Ari }\end{array}$ & Grafis \\
\hline & & $\begin{array}{l}\text { Ari mengutip sebuah } \\
\text { Hadits Nabi Saw. yang } \\
\text { diriwayatkan oleh Imam } \\
\text { Ibnu Majah dan Ahmad: } \\
\text { "Barang siapa datang ke } \\
\text { masjid tiada lain kecuali } \\
\text { untuk kebaikan, baik untuk } \\
\text { belajar maupun untuk } \\
\text { mengajar, maka nilainya } \\
\text { sama seperti berjibad di jalan } \\
\text { Allab Swt." }\end{array}$ \\
\hline
\end{tabular}




\section{Premis I}

Dalam serial film kartun CISForm: Jihad fi Sabilillah dapat ditemukan adanya perbedaan pemberian makna tentang Jihad fi Sabilillah antara Udin dan Ari. Sepertinya Udin dalam serial kartun tersebut merupakan tokoh yang memiliki pemahaman bahwa Jihad fi Sabilillah adalah dengan melalui ritual lahir atau fisik (baca: esoteric) misalnya, dengan demostrasi demi menegakkan Khilafah Islam di suatu negara demokrasi, perang dengan angkat senjata dan lain sebagainya.

Dari temuan di atas, mari kita bahas perlahan-lahan. Pertama, jihad menurut pandangan tokoh Udin untuk melakukan demostrasi menegakkan khilafah, dapat ditangkap bahwa Islam tidak boleh tunduk di hadapan kaum kafir. Sebagaimana yang dikatakan oleh Max Weber, bahwa Islam adalah agama Ksatria. Maka menjadi orang Islam haruslah ksatria, pantang untuk diinjak. Islam diturunkan oleh Allah untuk dimenangkan di atas semua agama dan aliran. Sementara sekarang ini Islam dipaksa untuk takluk di bawah ajaran non-Islam, yang diberi nama demokrasi. Maka demokrasi harus ditumbangkan, dan penganjur demokrasi paling utama, yakni Amerika pun harus dihancurkan. Dan meninggal dalam rangka meruntuhkan berhala demokrasi adalah mati Syahid. Kemudian, tokoh Udin juga memberikan pemaknaan bahwa jihad adalah perang. Sementara itu kita tahu bahwa jihad dalam arti perang defensif yang adil diperbolehkan oleh hukum Islam, dengan catatan sebagai berikut:

1. Tidak membunuh perempuan dan anak kecil.

2. Tidak membunuh 'asif (orang-orang yang dipekerjakan sebagai tentara).

3. Tidak membunuh syaikh fani (orang lanjut usia) yang tak mampu berperang.

4. Menyakiti para rahib dan rohaniawan.

5. Memotong-motong tubuh manusia. ${ }^{23}$

Sementara itu khalifah Abu Bakar ra. membuat ijtihad dalam hal ini:

1. Tidak boleh memusnahkan pohon kurma.

2. Tidak merusak lading gandum.

3. Tidak boleh menebang pohon yang mempunyai buah-buahan.

4. Tidak boleh membunuh atau membinasakan binatang ternak.

5. Tidak boleh menghancurkan biara. ${ }^{24}$

Sedangkan dalam hal bunuh diri, Islam melarang dengan tegas, dalam kondisi apapun. Larangan terkeras dapat ditemukan di hadits dengan pernyataan eksplisit: "Barangsiapa bunub diri, dia akan masuk neraka" dan "dijaubkan dari surga selama-lamanya".

Hal ini juga sejalan dengan riwayat bahwa Rasulullah saw. menolak ritual penguburan bagi seseorang yang melakukan bunuh diri. ${ }^{25}$ Nabi Muhammad Saw. mengisahkan cerita menyedihkan tentang seorang penghuni neraka. Dia berjuang bersama Nabi Saw. terluka dalam perang, tersungkur karena luka yang parah, terjatuh di atas pedangnya. ${ }^{26}$ Dalam versi yang lain dijelaskan, Nabi Saw. mengingatkan bahwa ada

${ }^{23}$ Ali Yasir, Jihad Masa Kini, 23

${ }^{24}$ Ali Yasir, Jihad Masa Kini, 23

25 Sunan Abu Daud, Vol. 2, 98

${ }^{26}$ al-Bukhari, Kitab Shabih, hadits no. 2683 dan 6012 
seorang manusia yang tampak di mata orang lain melakukan amalan ahli surga, tetapi dia dimasukkan ke neraka, dan seseorang yang tampak di mata orang lain melakukan amalan ahli neraka, tetapi dia dimasukkan ke surga. Selanjutnya, jihad juga dimaknakan oleh golongan esoterik (baca: lahir atau fisik) dengan bom bunuh diri, sebagaimana yang sekarang sedang menjadi suatu kegemaran di belahan dunia Islam, tanpa terkecuali Indonesia. Bom bunuh diri adalah fenomena tragis yang menyentak kita semua. Ia menyebabkan hilangnya nyawa-nyawa yang tak berdosa, dan mencerminkan suatu bentuk keputusasaan yang mendalam dan tiada harapan oleh para pelakunya. Ini adalah sebuah fenomena yang tidak bisa diterima oleh masyarakat beradab manapun, baik di dunia Islam maupun di Barat. Untuk memecahkan sebuah persoalan memerlukan pemahaman tentang akar-akarnya. Untuk memecahkan persoalan bom bunuh diri yang diklaim sebagai Jihad fi Sabilillah, kita perlu melebarkan pemikiran kita mengenai aspekaspek psikologis, sosisologis, bahkan bilogis guna menyelidiki impuls-impuls yang mendorong para pelakunya melakukan hal tersebut.

Seorang tokoh sosiologi bernama Emile Durkheim membuat pengamatan penting mengenai bunuh diri. Penemuan Durkheim yang paling kontraintuitif adalah bahwa tingkatan bunub diri adalah konstan bagi sebuah masyarakat tertentu. Bunuh diri cenderung merupakan masalah kolektif atau sosial daripada masalah individu, dan tingkatan bunuh diri yang umum hanya dapat dijelaskan secara sosiologis, bukan individual. Penyebab-penyebab individual terhadap bunuh diri sering kali sulit diidentifikasi karena pelakunya tidak menjelaskan tindakan mereka tersebut. Kita hanya dapat mengamati penyebab-penyebab uji coba bunuh diri yang gagal atau belajar dari pelaku yang meninggalkan penjelasan yang terperinci kepada kita. ${ }^{27}$ Durkheim menemukan bahwa secara statistik bunuh diri kurang berhubungan dengan fenomena individu daripada fenomena sosial, seperti asal keluarga, politik, dan ekonomi, serta kelompok agama. Hal-hal ini berkolerasi dalam sebuah masyarakat tertentu terhadap suatu kecenderungan kolektif untuk bunuh diri., "tingkat bunuh diri relatif konstan bagi setiap masyarakat selama dalam kondisi-kondisi dasar yang memicunya masih sama. Kecenderungan ini merupakan suatu kenyataan objektif yang bersifat eksterior terhadap individu dan memberikan dampak koersif terhadapnya. ${ }^{28}$

Sementara itu ada beberapa penjelasan yang lain seputar justifikasi legal yang diakui oleh para ahli fikih (baca: esoterik) mengenai bom bunuh diri. Banyak dari ahli fiqih yang mendefinisikan perbedaan pragmatis antara bunuh diri dan syubada. Pandangan ini berlaku karena rakyat Palestina merupakan korban dari pendudukan Israel dan telah lama menderita akibat permukiman illegal dan hilangnya rumah serta tanah air mereka, sehingga berdasarkan hukum Islam rakyat Palestina berhak membela diri mereka secara militer. Namun, rakyat Palestina tidak mempunyai angkatan militer konvensional yang dapat melindungi mereka, para ahli fiqih menggunakan aturan darurah untuk mengizinkan tindakan bom bunuh diri adalah masalah teologis, dan ini telah menjadi sesuatu yang dapat diterima di kalangan masyarakat Palestina sebagai satusatunya cara untuk menarik perhatian dunia Internasional atas keadaan yang mereka

${ }^{27}$ Emile Durkheim, Suicide, 1951 dalam Imam Feisal Abdul Rauf, Seruan Adzan Dari Puing WTC, 176-177

${ }^{28}$ Emile Durkheim, Suicide, 1951 dalam Imam Feisal Abdul Rauf, 177 
alami. Hal tersebut didukung juga oleh Majelis Ulama Indonesia (MUI), bahwa jihad dengan bom bunuh diri dan sejenisnya, tidak berlaku apabila dilakukan di Indonesia. Sebab, Indonesia bukanlah wilayah yang sedang terjadi konflik. ${ }^{29}$

Kemudian di samping itu, jihad yang kita artikan sebagai suatu kegiatan memerangi kekafiran haruslah ditempatkan dalam koridor yang jelas. Artinya, dalam jihad model ini prosedur maupun persyaratan di dalamnya sangat ketat, sebagaimana diantara syaratnya telah dipaparkan dalam tulisan ini diatas. Mirip dengan ketatnya persyaratan dalam melakukan amar ma'ruf terutama ketika sudah masuk dalam konteks bermasyarakat dan bernegara. Bagaimana mungkin perjuangan yang telah banyak mengabaikan etika maupun prosedur dalam berjihad bisa dinamakan jihad? Apalagi kekerasan yang dilakukan telah banyak melanggar baik syariat maupun norma-norma kemanusiaan, diantaranya: Pertama, jihad telah mengorbankan nyawa-nyawa yang tidak berdosa, di mualai dari anak-anak, wanita hingga orang tua. Kedua, merusak tatanan ekonomi dan sosial, hingga pada kahirnya mengancurkan sebuah negara dan memberanguskan komponen-komponen yang ada di dalamnya, serta membutuhkan waktu yang panjang untuk kembali memulihkan seperti sedia kala. Ketiga, media dan sarana yang digunakan sudah kontraproduktif dengan warna jihad yang digaungkan oleh Islam kala itu. Keempat, jihad sesungguhnya merupakan wewenang daripada suatu pemerintahan, dimana pemerintahan itu merupakan pemerintah yang sah dan disepakati oleh rakyatnya, sebagai contoh adalah jihad yang diserukan oleh KH Hasyim Asy'ari di Surabaya untuk melawan penjajahan yang dilakukan oleh sekutu kala itu. Pemerintahan yang sah dalam hal ini, Presiden Soekarno menyetujui dan mendukung kegiatan jihad tersebut.

\section{Premis II}

Tokoh Ari dalam memahami makna Jihad fi Sabilillab adalah dengan mempelajari ilmu pengetahuan dan mengamalkannya. Ari adalah tokoh yang memaknai jihad cenderung kepada hal-hal non-fisik (baca: akal dan batin/esoterik).

Kesalahan memahami jihad yang hanya dimaknai semata-mata perjuangan fisik disebabkan oleh tiga hal. Pertama, pengertian jihad secara khusus banyak dibahas dalam kitab-kitab fiqih klasik senantiasa dikaitkan dengan peperangan, pertempuran, dan ekspedisi militer. ${ }^{30} \mathrm{Hal}$ ini membuat kesan, ketika kaum Muslim membaca kitab fikih

${ }^{29}$ Pemahaman jihad dalam konteks ini, mengacu pada referensi diantaranya kitab jihad oleh Ahmad Muhammad al-Haufy, Jihad fi al-Islam baina ath-Thalab wa ad-Difa oleh Salih alLahidah; al-Jibad fi al-Islam, Dirasah Muqaranah bi al-Abkam al-Qanun al-'Amin oleh Taufiq Ali Wahbah; al-jibad fi al-Islam, kaifa Nafhamubu wa kaifa Numarisubui oleh Muhammad Said Ramadhan al-Buthi; al-Jihad fi Sabilillah dan Ayat al-Jibad fi al-Qur'an al-KARIM, Dirasab Maudhu'iyyah wa Tarikbiyyah wa Bayaniyyah oleh Kamil Salamah ad-Duqs.

${ }^{30}$ Pandangan jihad dalam bentuk ini diantaranya dikemukakan oleh Hasan al-Banna, pengertian perang untuk membela kebenaran dengan cara menyusun kekuatan militer dan melengkapi sarana pertahanan darat, laut dan udara pada setiap saat. (Hasan al-Banna, Risalah aljïhad, (Kuwait: al-Ittihad AL-'Alami li al-Munazhamat ath-Thullabiyyah, 1985), 7-59 
klasik, jihad hanya bermakna perang atau perjuangan fisik, tidak lebih dari itu. ${ }^{31} \mathrm{Kedua}$, kata jihad dalam al-Qur'an muncul pada saat-saat perjuangan fisik atau perang selama periode Madinah, di tengah berkecambuknya peperangan kaum Muslim membela keberlangsungan hidupnya dari serangan kaum kafir Quraisy dan sekutu-sekutunya. Hal ini menorehkan pemahaman bahwa jihad sangat terkait dengan perang. Menurut Daud Al-Aththar, salah satu karakteristik ayat surah Madaniyah adalah banyak menyebutkan ajaran tentang jihad, memberi izin untuk berperang dan menjelaskan tentang hukumhukumynya. ${ }^{32}$ Ketiga, terjemahan yang kurang tepat terhadap kata anfus dalam surah alAnfal ayat 72 yang artinya: "Sesunggubnya orang-orang yang beriman dan berbijrah serta berjihad dengan harta dan jiwanya pada jalan Allah dan orang-orang yang memberikan tempat kediaman dan pertoIongan (kepada orang-orang mubajirin), mereka itu satu sama lain lindung-melindungi. Dan (terhadap) orang-orang yang beriman, tetapi belum berbijrah, Maka tidak ada kewajiban sedikitpun atasmu melindungi mereka, sebelum mereka berbijrah. (akan tetapi) jika mereka meminta pertolongan kepadamu dalam (urusan pembelaan) agama, Maka kamu wajib memberikan pertolongan kecuali terhadap kaum yang telah ada Perjanjian antara kamu dengan mereka. dan Allah Maha melihat apa yang kamu kerjakan".

Kata anfus yang diterjemahkan dengan "jiwa", menurut Quraish Shihab tidak tepat dalam konteks jihad. Makna yang tepat dari kata anfus dalam konteks jihad adalah totalitas manusia, sehingga kata nafs (baca: kata tunggal dari anfus) mencakup nyawa, emosi, pengetahuan, tenaga dan pikiran.

Kesalahan yang sama juga dilakukan oleh para pengamat Barat yang sering mengidentikkan jihad dengan holy war atau perang suci. Jihad tidak berarti sebagai perang melawan orang kafir, tidak berarti perang yang semata-mata karena motif agama. Secara historis, jihad lebih sering dilakukan atas dasar politik, seperti perluasan wilayah Islam atau pembelaan diri kaum Muslim terhadap serangan yang dilakukan oleh musuh. Oleh sebab itu, holy war adalah terjemahan keliru dari jihad. Holy war dalam tradisi Kristen bertujuan mengkristenkan orang yang belum memeluk agama Kristen, sedangkan dalam Islam jihad tidak pernah bertujuan mengIslamkan orang non-Islam.

Munawar Khalil dalam buku kelengkapan Tarikh Nabi Muhammad Saw. mengutip pendapat Muhammad Abduh, Ibnu Qayyim dalam Zaad Al-Ma'ad dan Syaikh Tahnthawi Jauhari, menyatakan bahwa orang-orang kurang mengerti, menyangka, bahwa jihad itu tidak lain adalah berperang dengan kafir. Sebenarnya tidak begitu. Jihad itu mengandung arti, maksud, dan tujuan yang begitu luas. Diantaranya adalah memajukan pertanian, ekonomi, membangun negara, serta meningkatkan budi pekerti umat termasuk jihad yang tidak kalah pentingnya ketimbang berperang.

Sayyid Bakri bin Sayyid Muhammad Syatha Ad-Dimyati Asy-Syafi'i di dalam kitabnya yang berjudul Hasyiyah Tanatut Thalibin bahwa:

31 Ibnu Hazm, al-Muhalla, (Beirut: Dar al-Fikr, tth), Jilid IV, 291-354; al-Hawi al-Kabir, (Beirut: Dar al-Fikr, tt), Jilid XVIII, 109-128; Ibnu Rusyd, Bidayah al-Mujtabid wa Nibayah alMuqtashid, (Beirut: Dar al-Fikr, tt), Jilid I, 278-298; Wahbah az-Zuhaily, al-Figh al-Islami wa Adilatuh, (Beirut: Dar al-Fikr, 1989), Jilid VI, 411-424

32 Daud al-Aththar, Mu'jaz Ulum al-Qur'an, Alih bahasa oleh Muhammad Afif dan Ahsin Muhammad, Pespektif Baru Ilmu Agama, (Bandung: Pustaka Hidayah, 1994), 148; Masfuk Zuhdi, Pengantar Ulumul Qur'an, (Surabaya: Bina Ilmu, 1993), 76 
"Kewajiban jihad adalah washilah (perantara) bukan tujuan, karena tujuan perang aslinya adalah memberi hidayah atau petunjuk kebenaran. Oleh sebab itu membunuh orang-orang kafir bukanlah tujuan yang sebenarmya sehingga seandainya hidayah bisa disampaikan dan dihasilkan dengan menunjuk.kan dalil-dalil tanpa berperang, maka hal ini lebih utama daripada berperang". ${ }^{33}$

Merupakan suatu fakta besar yang menganga di depan kaum Muslim, Islam menjadi ketinggalan dalam kancah perkembangan dan kontestasi kemajuan ilmu pengetahuan dan tehnologi, karena disibukkan dengan hal-hal yang sebenarnya tidak perlu untuk diributkan dan diperdebatkan dengan panas nalar dan akal yang mendidih, namun pada kenyataannya masyarakat Islam tidak mampu untuk berfikir dan bersifat dewasa untuk setingkat lebih maju daripada bangsa Barat, khususnya adalah Amerika dan Israel dalam percaturan kemajuan khazanah kelimuan. Padahal sejarah telah mecatatkan, betapa Islam telah melahirkan mujabid-mujahid ilmu pengetahuan yang dihargai oleh dunia Barat kala itu, hingga penemuan-penemuan mereka tentang sains dan rantingnya mampu dimanfaatkan oleh dunia eropa dan Amerika yang notabene adalah negara-negara terbelakang dalam berpengetahuan dikala itu.

Menuntut ilmu agama dan ilmu pengetahuan umum, mampu juga dikatakan sebagai jihad. Bahkan sebagian ulama mengatakan bahwa jihad dengan ilmu ini lebih utama daripada dengan senjata. Karena setiap jihad mesti pula didahului dengan ilmu. Karena menjaga syariat adalah dengan ilmu. Jihad dengan senjata pun harus dengan ilmu. Tidaklah bisa seseorang ber-jïhad, mengangkat senjata, mengatur strategi, membagi ghonimah (baca: harta rampasan perang), menawan tahanan melakukan harus dengan ilmu. Ilmu itu adalah sebagai dasar. ${ }^{34}$

Adapun dalil yang mendukung bahwa menuntut ilmu termasuk jihad adalah tertuang dalam al-Qur'an surah al-Furqon: 51-52 yang artinya: "Dan andaikata Kami menghendaki benar-benarlah Kami utus pada tiap-tiap negeri seorang yang memberi peringatan (rasul). Maka janganlah kamu mengikuti orang-orang kafir, dan berjihadlah terhadap mereka dengan Al Quran dengan Jihad yang besar".

Ibnul Qayyim menerangkan di dalam kitabnya yang berjudul Zaadul Ma'ad, bahwa surah ini adalah termasuk dalam surah Makkiyah, artinya adalah surah yang diturunkan kepada Nabi Muhammad Saw. sebelum beliau berhijrah. Di dalam ayat ini berisi perintah ber-jihad melawan orang kafir dengan hujjah dan bayan (dengan memberi penejasan atau ilmu, karena saat itu kaum muslimin belum mempunyai kekuatan untuk ber-jïhad menggunakan senjata. Bahkan jihad melawan orang-orang yang munafik itu lebih berat dibanding berjihad melawan orang kafir. Jihad dengan ilmu inilah jihadnya orang-orang yang khusus dari umat ini yang menjadi pewaris para Rasul. ${ }^{35}$

Sedangkan dalam hadits juga disebutkan bahwa menuntut ilmu adalah bagian daripada jihad sebagaimana yang katakana oleh tokoh Ari ketika menutup percakapan

33 Sayyid Bakri, Hasyiyah Tanatut Thalibin ( Beirut: Darul Fikr, 2006), cet. Kelima, jilid IV, 181.

${ }^{34}$ Syarh daripada Riyadhus Sholibin, Jilid 1, 108

35 Ibnu Qayyim al-Jauziah, Mukhtashar Zaadul Ma'ad, diringkas oleh Muhammad bin Abdul Wahab at-Tamimi, Darul Fikr, 1990. Diterjemahkan oleh Kathur Suhardi, Mukbtashar Zaaadul Ma'ad: Bekal Menuju Akhirat, (Jakarta: Pustaka Azam, 2000), 174 
yang dilakukannya dengan tokoh Udin di dalam serial film kartun CISForm: Jihad fi sabilillah tersebut. Rasulullah Saw. bersabda:

Artinya: "Siapa yang mendatangi masjidku (masjid Nabawi) lantas ia mendatanginya hanya untuk. niatan yang baik yaitu untuk belajar atau mengajarkan ilmu di sana, maka kedudukannya seperti mujahid di jalan Allah. Jika tujuannya tidak seperti itu, maka ia hanyalah seperti orang yang mentilik-tilik barang lainnya". ${ }^{36}$

\section{Penutup}

\section{Kesimpulan}

Berdasarkan analisis wacana yang peneliti lakukan terhadap serial film kartun CISForm: Jihad fi Sabilillah, maka dapat disimpulkan bahwa Jihad fi Sabilillah mampu dilakukan dengan beragam cara, tidak dengan demostrasi dan perang. Sebab, jihad bentuk demostrasi untuk penegakan khilafah dan perang dalam konteks tatanan dunia sekarang sudah tidak mungkin untuk dilaksanakan. Dan menyalahi pemaknaan dan penerapan ayat-ayat tentang jihad di al-Qur'an maupun Sunnah Nabi Saw. Jihad di masa kini harus mempunyai arah untuk memajukan Islam demi kemaslahatan manusia dan alam semesta, diantaranya adalah dengan membongkar khazanah-khazanah keilmuan yang masih terpendam untuk menjawab persoalan-persoalan yang dihadapi oleh dunia, tanpa terkecuali dunia Islam sendiri. Sehingga dapat dikatakan bahwa, Jihad dengan mempelajari ilmu agama atau ilmu pengetauan yang lainnya, lebih utama kedudukannya ketimbang dengan jihad mengangkat senjata.

\section{Daftar Pustaka}

Al-Aththar, Daud, Mu'jaz Ulum al-Qur'an, Alih bahasa oleh Muhammad Afif dan Ahsin Muhammad, Pespektif Baru Ilmu Agama, Bandung: Pustaka Hidayah, 1994.

Al-Banna, Hasan. Risalah al-jihad, Kuwait: al-Ittihad AL-'Alami li al-Munazhamat athThullabiyyah, 1985.

Al-Bukhari, Al-Jami' al-Musnad as-Shabih al-Mukhtasar min Umur Rasulillah SAW wa Sunanibi wa Ayyamibi, Dar al-Sya'ab, t.t., t.th.

Al-Ghazali, Abu Hamid, Ibya' 'Ulum al-Din diterjemah oleh Tengku Muhammad Habsi ash-Shidiegh, Semarang: Pustaka Riski, 2003.

al-Jauziah, Ibnu Qayyim, Mukhtashar Zaadul Ma'ad, diringkas oleh Muhammad bin Abdul Wahab at-Tamimi, diterjemahkan oleh Kathur Suhardi, Mukbtashar Zaaadul Ma'ad: Bekal Menuju Akhirat Jakarta: Pustaka Azam, 2000.

Al-Qur'an dan Terjemahannya, Departemenen Agama RI, Jakarta, 1978/1979.

${ }^{36}$ HR. Ibnu Majah no. 227 dan Imam Ahmad no. 418 
Arikunto, Suharsimi, Prosedur Penelitian: Suatu Pendekatan Praktek. Jakarta: Rineka Cipta, 2010.

Az-Zuhaily, Wahbah, al-Fiqh al-Islami wa Adilatuh, Beirut: Dar al-Fikr, Jilid VI, 1989.

Bakri, Sayyid, Hasyiyah Tanatut Thalibin cet. Kelima, jilid IV, Beirut: Darul Fikr, 2006.

Bellah, Robert, The Good Society, 1992.

Dawud, Abu. Sunan Abu Dawud, Mishr: Maktabat Mushthafa al-Babi al-Halabi, 1952.

Drajat, Zakariya, Jihad Dinamis: Menelusuri Konsep dan Praktik Jihad Dalam Sejarah Islam, Jurnal Wacana Hukum Islam dan Kemanusiaan, Vol. 16. No. 1, Jakarta: Universitas Negeri Jakarta, 2016.

Eriyanto. Analisis Wacana: Pengantar Analisis Teks Media, Yogyakarta: LKiS. 2015.

Fatah, Abdul, Memaknai Makna Jihad Dalam al-Qur'an dan Tinjauan Historis Penggunaan Istilah Jibad Dalam Islam, Jurnal Pendidikan Agama Islam, Vol. 3, No. 1 Juli-Desember, Malang: Universitas Negeri Malang (UIN) Maulana Malik Ibrahim, 2016.

Hazm, Ibnu, al-Muballa, Beirut: Dar al-Fikr, Jilid IV, th., al-Hawi al-Kabir, Beirut: Dar al-Fikr, Jilid XVIII, tth.

Ilahi, Wahyu.dkk. Komunikasi Dakwah. Surabaya: IAIN Sunan Ampel Press. 2013.

Imam Feisal, A. Rauf. Seruan Adzan Dari Puing WTC: Dakwah Islam Di Jantung Amerika Pasca 9/11. Bandung: Mizan Pustaka. 2004.

Irawan, Deni. Kontroversi Makna dan Konsep Jihad Dalam al-Qur'an Tentang Menciptakan Perddamaian, Jurnal Religi, Vol X, No. 1. Yogyakarta: Universitas Islam Negeri (UIN) Sunan Kalijaga. 2014.

Moelong, Lexy J. Metode Penelitian Kualitatif. Bandung: Remaja Rosdakarya. 2003.

Mulkhan, Abdul Munir. Arah Ideologi Gerakan Dakwah. Yogyakarta: SIPRESS. 1996.

Qutb, Sayyid. Tafsir Fi Zilal al-Qur'an Jilid 8. Jakarta: Gema Insani Press. 2003.

Rusyd, Ibnu, Bidayah al-Mujtabid wa Nihayah al-Muqtashid, Beirut: Dar al-Fikr, Jilid I, th.,

Saleh, Hasan. Kajian Fiqih dan Fiqih Kontemporer. Jakarta: IT Raja Persada. 2004.

Sobur, Alex. Analisi Teks Media. Bandung: Rosdakarya. 2003.

Sugiyono. Metode Penelitian Kuantitatif, Kualitatif dan R\&D. Bandung: Alfabeta. 2014.

Taimiyah, Ibnu , As-Siyasah asy-Syar'iyah fi Ishlahi ar-Ra'I wa al-Ra'iy-yah, (Mesir: Dar alKitab al-'Arabi, 1951.

Yasir, S. Ali. Jihad Masa Kini. Jakarta: Darul Kutubil Islamiyah. 2005.

Zuhdi, Masfuk, Pengantar Ulumul Qur'an, Surabaya: Bina Ilmu, 1993. 
20 |Jurnal Dakwah dan Komunikasi, Vol. 4 , No.1, 2019

\section{Sumber Website:}

http://Republika.co.id

http://uin-suka.ac.id

http://youtube.com 